\title{
Efficacy of Synbiotics as an Adjunct to Antibiotic Therapy in Diarrhoeic Cattle
}

\author{
Rashmi Lata Rakesh ${ }^{1}$, B. Roopali ${ }^{1}$, M. $\operatorname{Roy}^{2}$, S. Roy ${ }^{1}$, S. K. Sidar ${ }^{3}$, \\ R. S. Kashyap ${ }^{1}$, H. K. Ratre ${ }^{4}$ and J. Singh ${ }^{5}$ \\ ${ }^{1}$ Department of Veterinary Medicine, ${ }^{2}$ Department of Veterinary Physiology and \\ Biochemistry, ${ }^{3}$ Department of Veterinary Surgery and Radiology, ${ }^{4}$ Department of Teaching \\ Veterinary Clinical Complex, ${ }^{5}$ Department of Wildlife health and Forensic Centre \\ College of Veterinary Science \& A.H., Anjora, Durg, Chhattisgarh, India \\ *Corresponding author
}

\section{Keywords}

Synbiotics, Antibiotic therapy, Diarrhoeic cattle, Hematobiochemical alterations

Article Info

Accepted:

15 December 2019

Available Online:

20 January 2020

\section{A B S T R A C T}

Diarrhoea is one of the most important problem causing great economic loss to dairy industry by drastic reduction in milk production. The present study was carried out in cattle reared at different organized dairy farms in and around Durg to evaluate the therapeutic efficacy of synbiotics along with antibiotic in diarrhoeic cattle. A total of 18 cattle were selected and divided into three groups. Group I $(n=6)$ served as normal healthy control whereas group $(n=6)$ II and III were diarrhoeic cattle. Group II animals were treated with ciprofloxacin @ $5 \mathrm{mg} / \mathrm{kg}$ orally twice daily for 5 days and Group III were administered with combination of ciprofloxacin@ $5 \mathrm{mg} / \mathrm{kg}$ orally BID for 5 days and symbiotic $\left(\operatorname{Ecotas}^{\circledR}\right)$ two boli orally OD for 5 days. Escherichia coli $(66.11 \%)$ was found to be most common pathogen involved in cattle diarrhoea followed by Salmonella spp. (22.22\%) and Proteus spp. (16.66\%) respectively. The hemato-biochemical alterations revealed significant increase in haemoglobin, PCV, TEC, TLC, neutrophils, total protein, albumin, albumin: globulin ratio and potassium values whereas, there was a significant decrease in lymphocyte, monocyte, eosinophil, globulin, sodium and glucose levels which returned near to normal values over the due course of treatment period in Group III followed by Group II. Rumen function profile revealed significant decrease in rumen $\mathrm{pH}$, sedimentation activity time and protozoan motility values, while cellulose digestion and methylene blue reduction values were increased in diarrhoeic cattle. The rumen function profile returned to normal in Group III followed by Group II. Hence, combination of antibiotic along with symbiotic proved to be a better alternative when compared to antibiotic alone for therapeutic management of diarrhoea in cattle.

\section{Introduction}

Gastrointestinal infections are one of the most common illness caused by different groups of microorganisms and these are leading cause of death in India. Among GIT infections diarrhea is commonly reported which is defined as an increased frequency, fluidity or volume of faecal excretion. In diarrhoea, the clinico-biochemical alterations are complex in 
nature characterized by imbalance of fluid, electrolyte and acid-base status (Radostits et al., 2010). Maintaining a healthy gastrointestinal microbiota is critical for the health and productivity of ruminants. However, antibiotic administration in cattle is widely used for the treatment of gastrointestinal infections. Antibiotic therapy may disturb the indigenous microbiota as well as increased antibiotic-resistant genes in dairy cows (Liu et al., 2016). Antibiotics suppress the rumen and intestinal microflora which ultimately leads to production losses and prolonged the recovery (Ravi et al., 2015). Now a days, the emergence of antibiotic resistance in the human commensal bacteria has raised concerns about the impact of antimicrobial compounds for agriculture use and has accelerated the search for alternative nutritional strategies, such as the addition of probiotics and prebiotics (Verstegen and Williams, 2002).Considering the above issues, the present work was designed to compare the efficacy of synbiotic along with antibiotic therapy.

\section{Materials and Methods}

The present study was carried out in cattle reared in different organized dairy farms, in and around Durg district of Chhattisgarh. Cattle showing watery diarrhoea were included. Gross examination of faeces was done to study the following parameters: fluidity of faeces, colour of faeces and presence of mucous and blood. Therapeutic management with antibiotic was based on the antibiotic sensitivity test of rectal swabagainst commonly used antibiotic discs (Hi Media, Limited, Mumbai) (Manickam and Ponnusamy, 2017). Two different treatment strategies were used for the therapeutic management of cattle affected with diarrhoea and the therapeutic efficacy of the drugs were assessed on the basis of faecal examination along with restoration of haematobiochemical and rumen function profile.
Group II animals were treated with ciprofloxacin@5 mg/kg orally twice daily for 5 days and Group III were administered with combination of ciprofloxacin@ $5 \mathrm{mg} / \mathrm{kg}$ orally BID for 5 days and symbiotic (Ecotas ${ }^{\circledR}$ ) two boli orally OD for 5 days.

\section{Haematol-biochemical parameters}

About $5 \mathrm{ml}$ blood was collected aseptically from jugular vein of all diarrhoeic and healthy cattle in EDTA coated vial using 16 gauge needle on day 0 (pre-treatment) and day 5 (post-treatment) for haemato-biochemical studies.

Haematological parameters like haemoglobin (gm/dl), TEC (millions per cubic millimeter $\left(10^{6} / \mathrm{mm}^{3}\right)$, PCV $(\%)$, TLC (thousands per cubic millimeter $\left(10^{3} / \mathrm{mm}^{3}\right)$ and DLC $(\%)$ were estimated by Vet MS39 semiautomatic haematological analyzer of MeletSchloesing Laboratories of Sussi France.

Serum samples were harvested from blood from diarrhoeic and healthy cattle in serum vials on day 0 (pre-treatment) and day 5 (post treatment). Biochemical parameters like glucose $(\mathrm{mg} / \mathrm{dl})$, total protein $(\mathrm{g} / \mathrm{dl})$, albumin (g/dl), globulin (g/dl), albumin-globulin ratio, aspartate aminotransferase (AST, U/L), alanine aminotransferase (ALT, U/L) were estimated by DiaSIL-100 semiautomated Biochemistry Analyzer (Systronics India Limited), as per the standard method and procedures given in commercial kits supplied by ARKRAY Healthcare Pvt. Ltd. Serum sodium (mmol/l) and potassium ( $\mathrm{mmol} / \mathrm{l})$ were estimated by using microprocessor based flamephotometer Model- 1382/1385 (ESICO).

\section{Rumen fluid examination}

Rumen fluid samples from all diarrhoeic and healthy cattle were collected by needle puncture of the rumen (rumenocentesis) from 
left lower paralumbar fossa (Petrovski, 2017). The following parameters were evaluated on day 0 and 5of the study:

A. Physical parameters: Colour, odour, consistency and Sedimentation Activity Test (SAT).

B. Chemical parameters: $\mathrm{pH}$ and Cellulose Digestion Test (CDT)

C. Microbial parameters: Rumen bacteria (gram staining and methylene blue reduction test), rumen protozoa by microscopic examination and protozoan motility

\section{Statistical analysis}

The results obtained were tabulated and subjected to statistical analysis by Completely Randomized Design (C.R.D.) as per the procedure outlined by Snedecor and Cochran (1994) by using IBM SPSS statistics.

\section{Results and Discussion}

\section{Fecal examination}

Examination of feces revealed that the faecal discharge in all diarrhoeic cattle varied in consistency from watery to loose with mucous and yellowish white in colour as compared to green or brownish olive solid faeces in animals of healthy control group (Group I) on day 0. However, on day 5 following treatment, fecal examination of animals of all treated groups revealed green or brownish olive solid faeces without mucous. In the present study, faecal examination of diarrhoeic revealed that the faecal discharge varied in consistency loose to watery with mucous and yellowish white in colour. The observations are in accordance with the findings of Shekhar et al., (2017). Yellowish white diarrhoeic faeces might be due to high content of salt particularly bicarbonate (Ward,
1976) with heavy secretion of water in intestinal lumen (Szancer, 1980). The findings of faecal examination revealed maximum improvement of different parameters in the animals of group III, followed by group II respectively. Escherichia coli $(66.11 \%)$ was considered to be most common pathogen involved in cattle diarrhoea followed by Salmonella spp. (22.22\%) and Proteus spp. $(16.66 \%)$ respectively.

\section{Haematological parameters}

\section{Haemoglobin (g/dl)}

The changes in haemoglobin, PCV, TEC, TLC and WBC were studied on $0^{\text {th }}$ and $5^{\text {th }}$ day (Table 1).

The present study elucidated a significant $(\mathrm{P}<0.01) \quad$ increase inhaemoglobin concentration in diarrhoeic animals as compare to the healthycontrol group. Restoration of haemoglobin value was recorded in treatment groups. The findings of increased haemoglobin values on the day 0 in the present study are in corroboration with the findings of Shekhar et al., (2017). The mean haemoglobin values in diarrhoeic cattle were found to be increased, which might be due to haemoconcentration because of dehydration and drainage of a large quantum of body fluids in watery purgation. However, in contrast to our findings, non-significant changes in haemoglobin values have been observed by Singh et al., (2014).However, Jain et al., (2016) reported that the $\mathrm{Hb}$ concentration was significantly $(\mathrm{P}<0.05)$ decreased in the clinical cases of bovine diarrhoea.

A highly significant $(\mathrm{p}<0.01)$ decrease in PCV values was recorded in the animals of groupII and III on day 5 following treatment as compared to day 0.The findings of present study are in accordance with those reported 
by Roy et al., (2009) and Shekhar et al., (2017) who have also reported that increase in PCV values in diarrhoeic cattle might be due to haemoconcentration associated with dehydration and hypovolemia.

Significantly $(p<0.05)$ higher TEC values were recorded in animals of group III followed by group II respectively on day 5 following treatment. The mean TEC values toward the end of study period were recorded to be within normal range.

The findings of the present study are accordance with Shekhar et al., (2017) who have also reported that mean TEC values in diarrhoeic cattle were found to be increased, which might be due to loss of extracellular fluid in diarrhoea which leads to haemoconcentration and hypovolemia.

The result of present study revealed a significant $(\mathrm{P}<0.01)$ increase in TLC values in the animals of all groups with diarrhoea on the pre-treatment day as compare to the healthy control group. The post therapeutic TLC value decreased on day 5 following treatment in all treated groups but maximum restoration was observed in Group III which was treated with ciprofloxacin along with ecotas. The findings of increased TLC values on the day 0 in the present study are in corroboration with the findings of Shekhar et al., (2017). Leukocytosis might have occurred due to normal reaction of body defense mechanism against infection and also due to dehydration and haemoconcentration. However, the reduction in TLC values following treatment might be due to control of infection in the patients during our study period. The combination of potent antibacterial agent and synbiotic might have blocked the rapid multiplication of pathogenic bacteria in the present therapeutic trial (Sharma et al., 2016).
A non-significant ( $>00.05)$ decrease in neutrophil percentage was recorded in animals of group I (Healthy control) on day 5 as compared to day 0 of treatment. However, a highly significant $(\mathrm{p}<0.01)$ decrease in neutrophil percentage values were recorded in the animals of group II and III on day 5 following treatment as compared to day 0 . At the end of observation period (day 0), lymphocyte and neutrophil percentage was recorded to be well within normal physiological values.

The eosinophil percentage in all animals after treatment decreased significantly $(\mathrm{p}<0.001)$. However, maximum decrease was observed in the animals of group III and II respectively following treatment. Percentage of eosinophil was recorded to be well within normal physiological values after treatment. Eosinopenia might have occurred due to active infectious process (Smith, 1996). The findings of normal eosinophil count in the present study corroborates with the findings of Jain et al., (2016) wherein they have reported non-significant changes in eosinophil values in bovine suffering from diarrhoea.

The mean basophil percentage values differed non-significantly $(p>0.05)$ in animals of all treatment groups at different intervals as compared to that of healthy control group on day 0 and day 5 . However, the mean values of healthy control group remained within the range on day 5 (post-treatment).The findings of non-significant changes in basophil values in our study are in concordance with the findings of Asati et al., (2008) wherein they have also reported non-significant changes in basophil percentage in cattle suffering from diarrhoea.

The lymphocyte percentage increased significantly $(\mathrm{p}<0.001)$ in the animals of group III and II respectively following treatment. At the end of observation period 
(day 5), lymphocyte percentage was recorded to be well within normal physiological values.

The monocyte percentage of all the treated groups decreased significantly $(\mathrm{p}<0.01)$ as the treatment proceeded. However, maximum decrease in monocyte percentage was observed in the animals of group III and II respectively following treatment which returned near to normal values on day 5 . Monocytopenia might be occurred due to endotoxins (Smith, 1996). The findings of normal monocyte count in the present study corroborates with the findings of Jain et al., (2016) wherein they have reported significant changes in monocyte values in bovine suffering from diarrhoea. However, Asatiet al., (2008) reported non-significant changes in monocyte values in diarrhoeic cattle. Shekhar et al., (2017) have also reported significant increase in monocyte count in diarrhoeic calves.

The marked neutrophilic response with lymphopenia is characteristic of acute bacterial enteritis (Malik et al., 2013) and the findings of reduced lymphocyte count in the present study might be attributed to the fact that neutrophilia leads to concurrent lymphopenia (Schalmet al., 1975).

\section{Biochemical parameters}

Mean \pm SE of glucose, total protein, albumin, globulin, A:G ratio, AST, ALT, serum sodium and potassium at various intervals of treatment ( $0^{\text {th }}$ day and $5^{\text {th }}$ day) (Table 2$)$.

A non-significant $(p>0.05)$ increase in blood glucose value was recorded in animals of group I (Healthy control) on day 5 as compared to day 0. However, a highly significant $(\mathrm{p}<0.001)$ increase in blood glucose values was recorded in the animals of group II and III on day 5 following treatment as compared today 0.Hypoglycaemia might have occurred as a result of reduced rate of conversion of lactic acid to glucose (Morris et al., 1985). Other factors involved in causing hypoglycaemia in diarrhoeic cattle might include anorexia, decreased intestinal absorption of glucose, alteration in tissue metabolism caused by decreased blood flow and oxygenation associated with hypovolemic shock (Bywater, 1977). The findings of decreased glucose values on the day 0 in the present study are in corroboration with the findings of Shekhar et al., (2017).

The noticeable increase in the level of total serum protein (TSP) values in diarrhoeic cattle as compared to healthy control animals is in close agreement with Singh et al., (2014). Earlier investigators (Shekhar et al., 2017) have also reported increase in serum total protein concentration in clinical cases of cattle diarrhoea. The marked increases in total serum protein in diarrhoeic cattle might be observed apparently due to associated dehydration. Walker et al., (1998) observed the significant increase in both PCV and TSP, which indicates hypovolemia, hemoconcentration and reduced glomerular filtration rate.

The noticeable increase in the level of albumin in diarrhoeic cattle as compared to healthy control animals is in close agreement with Singh et al., (2014). A significant increase in serum albumin concentration in the diarrhoeic cattle has also been reported by the earlier investigators (Shekhar et al., 2017). The apparent hyperalbuminemia observed in the study might be due to definitive bioresponse to abnormal loss of body fluids.

A non-significant $(p>0.05)$ increase in globulin value was recorded in animals of group I (Healthy control) on day 5 as compared to day 0 of observation period. However, a highly significant $(\mathrm{p}<0.01)$ increase in globulin values was recorded in 
the animals of group II and III on day 5 following treatment as compared to day 0.The globulin values of all the treated groups increased significantly $(\mathrm{p}<0.01)$ after initiation of therapy. However, maximum increase was observed in the animals of group III followed by group II respectively.

The $A: G$ ratio values of all the treated groups decreased significantly $(\mathrm{p}<0.01)$ after treatment. The findings of increased $\mathrm{A}: \mathrm{G}$ ratio values on the day 0 of treatment in the present study are in corroboration with the findings of Singh et al., (2014). A significant increase in A: $G$ ratio has also been observed in diarrhoeic cattle which might be due to either increase in albumin or due to dehydration (Kaneko, 2008), or decrease in globulin. In contrast to our findings, decreased $A: G$ ratio in diarrhoeic cattle has been reported by Rekha et al., (2011).

The mean AST values differed nonsignificantly $(p>0.05)$ in animals of all treatment groups at different intervals as compared to that of healthy control group on day 0 and day 5 of treatment. However, the mean values of healthy control group remained within the range on day 5 (posttreatment).Similar type of findings has also been reported by Singh et al., (2014). Nonsignificant changes in AST activities were observed in diarrhoeic calves which indicate the absence of marked hepatic damage (Lewis et al., 1975). In contrast to our findings, significant increase in the activities of AST in diarrhoeic calves as compared to normal ones has been reported by Galbat et al., (2015).

A non-significantly ( $p>0.05)$ differed mean ALT values were recorded in animals of all treatment groups at different intervals as compared to that of healthy control group on day 0 and day 5 of treatment. However, the mean values of healthy control group remained within the range on day 5 (post-
treatment).Similar type of findings has also been reported by Shekhar et al., (2017). Nonsignificant changes in ALT activity indicate the absence of marked hepatic damage (Lewis et al., 1975). In contrast to our findings, Galbat et al., (2015) reported a significant increase in the ALT activities diarrhoeic calves.

The serum sodium values of all the treated groups increased significantly $(\mathrm{p}<0.01)$ after initiation of therapy. However, maximum increase was observed in the animals of group III followed by group II respectively. Hyponatremia in diarrhoeic cattle might have occurred due to excessive secretion of the sodium ions by intestinal villus which is lost through the intestinal tract particularly in enterotoxigenic $E$. coli induced diarrhoea (Radostitset al., 2010).

Most of the diarrhoea causing microorganisms disrupt the intestinal function and dehydrate the body either by increasing the chloride-secreting activity of the crypt cell or impairing the absorption of sodium by the villus cells or both. Hence, the fluid that is normally returned to the blood across the intestinal wall is lost in the watery stool (Hirschhorn and Greenough III, 1991).

The serum potassium values of all the treated groups decreased significantly $(\mathrm{p}<0.01)$ after treatment. However, maximum decrease was observed in the animals of group III and II respectively.

Hyperkalaemia might be due to increased potassium retention by kidney and also due to consequence of accelerated leakage of intracellular potassium across the structurally altered plasma membranes of damaged cells into the fluid compartment of circulating blood (Fisher and Dela Fuente, 1971) or it may be due to metabolic acidosis which might have induced translocation of potassium ions 
from intracellular to extracellular compartment (Shrivastava et al., 2001).

\section{Rumen liquor examination}

The changes in physical parameters, chemical parameters and microbiological parameters of rumen fluid were studied and their levels at various intervals of treatment ( 0 and $5^{\text {th }}$ day).

Evaluation of rumen fluid revealed that the colour of rumen fluid in animals of group I and II varied from brown to light brown in colour as compared to yellowish brown or brownish green colour in the animals of group I (Healthy control) on day 0 of study. However, on day 5 following treatment, the colour of rumen fluids was yellowish brown or brownish green in animals of group I and III as compared to light brown colour in animals of group II.

Evaluation of rumen fluids revealed that odour of rumen fluid in the animals of group II and III was acidic as compared to aromatic odour of rumen fluid in the animals of group I (Healthy control) on day 0 . However, on day5 following treatment the odour of rumen fluid in the animals of group I and III was aromatic as compared to acidic odour in animals of group II.

Evaluation of rumen fluids revealed that the consistency of rumen fluids in the animals of group II and III was watery as compared to slightly viscous consistency in the animals of group I (Healthy control) on day 0 .

However, on day 5 following treatment the consistency of rumen fluid was slightly viscous in the animals of group I and III as compared to watery consistency in group II. The watery consistency characteristics might be due to the presence of inactive bacteria and protozoa (Arsat et al., 2015).
Sedimentation activity test (SAT in minutes)

Mean \pm SE of SAT (minutes) on day 0 in group I, II and III were $7.17 \pm 0.31,2.33 \pm 0.21$, $2.25 \pm 0.25$, respectively. Similarly the SAT (minutes) values in group I, II and III on day 5were $\quad 7.50 \pm 0.22, \quad 4.50 \pm 0.22, \quad 8.33 \pm 0.25$ respectively. The SAT values of all the treated groups increased significantly $(p<0.01)$ after initiation of therapy. However, maximum increase was observed in the animals of group III followed by group II respectively. The results of the present study with very rapid sedimentation to no floatation might be related to the prolonged anorexia, rumen acidosis and inactive ruminal microflora (Smith, 1996).

\section{Chemical parameters}

\section{Rumen pH}

A non-significant $(\mathrm{p}>0.05)$ decrease in rumen $\mathrm{pH}$ value was recorded in animals of group I (Healthy control) and group II on day 5 as compared to day 0. However, a highly significant $(\mathrm{p}<0.01)$ increase in SAT values were recorded in the animals of group III on day 5 following treatment as compared to day 0 . Presumably, in the present therapeutic trial the restoration of rumen $\mathrm{pH}$ in animals treated with synbiotics might be due to beneficial effect of synbiotics on the balance of rumen microbiota and thereby the stabilization of $\mathrm{pH}$ value (Habeeb, 2017).

\section{Cellulose digestion test}

Maximum decrease in CDT values was observed in the animals of group III followed by group II post-treatment. In the present therapeutic trial, the decrease in CDT values in animals treated with synbiotics might be due to beneficial effect of synbiotics which stimulate total and cellulolytic bacterial numbers in rumen fluid (Shakira et al., 2018). 
Table.1 Haematological changes in healthy and diarrhoeic animals on day 0 and 5

\begin{tabular}{|c|c|c|c|}
\hline \multirow[t]{2}{*}{ Parameters } & \multirow[t]{2}{*}{ Groups } & \multicolumn{2}{|c|}{ Treatment intervals (Days) } \\
\hline & & 0 & 5 \\
\hline \multirow{3}{*}{ Haemoglobin (g/dl) } & I & $11.09^{\mathrm{b}} \pm 0.20$ & $11.30^{\mathrm{ab}} \pm 0.19$ \\
\hline & II & $13.40^{\mathrm{a}} \pm 0.18$ & $11.62^{\mathrm{a}^{* * *}} \pm 0.06$ \\
\hline & III & $12.94^{\mathrm{a}} \pm 0.13$ & $11.15^{\mathrm{ab**} \pm 0.17}$ \\
\hline \multirow{3}{*}{$\operatorname{TEC}\left(10^{6} / \mathrm{mm}^{3}\right)$} & I & $7.37^{\mathrm{c}} \pm 0.04$ & $7.59^{\mathrm{a}} \pm 0.14$ \\
\hline & II & $9.09^{\mathrm{a}} \pm 0.15$ & $6.97^{b * *} \pm 0.15$ \\
\hline & III & $8.72^{b} \pm 0.06$ & $7.47^{\mathrm{a}^{* *}} \pm 0.02$ \\
\hline \multirow{3}{*}{$\operatorname{PCV}(\%)$} & I & $35.47^{\mathrm{C}} \pm 0.63$ & $36.18^{\mathrm{ab}} \pm 0.22$ \\
\hline & II & $42.95^{\mathrm{a}} \pm 0.19$ & $37.10^{\mathrm{a}^{* * *}} \pm 0.20$ \\
\hline & III & $40.77^{\mathrm{b}} \pm 0.29$ & $35.82^{\mathrm{b}^{* * *}} \pm 0.50$ \\
\hline \multirow{3}{*}{$\operatorname{TLC}\left(10^{3} / \mathrm{mm}^{3}\right)$} & I & $9.89^{c} \pm 0.12$ & $9.73^{\mathrm{a}} \pm 0.22$ \\
\hline & II & $13.78^{\mathrm{a}} \pm 0.16$ & $10.04^{\mathrm{a}^{* * *}} \pm 0.23$ \\
\hline & III & $13.61^{\mathrm{a}} \pm 0.20$ & $8.39^{\mathrm{b} * *} \pm 0.02$ \\
\hline \multirow{3}{*}{$\begin{array}{l}\text { DLC } \\
\text { Neutrophils (\%) }\end{array}$} & I & $29.80^{\mathrm{b}} \pm 0.16$ & $29.62^{\mathrm{b}} \pm 0.12$ \\
\hline & II & $57.28^{\mathrm{a}} \pm 0.12$ & $30.87^{\mathrm{a}^{* * *}} \pm 0.28$ \\
\hline & III & $56.85^{\mathrm{a}} \pm 0.21$ & $29.65^{\mathrm{b} * *} \pm 0.18$ \\
\hline \multirow{3}{*}{ Eosinophils (\%) } & I & $2.23^{\mathrm{a}} \pm 0.03$ & $2.25 \pm 0.02$ \\
\hline & II & $1.47^{b} \pm 0.08$ & $2.33^{* *} \pm 0.04$ \\
\hline & III & $1.28^{\mathrm{b}} \pm 0.09$ & $2.30^{* *} \pm 0.04$ \\
\hline \multirow{3}{*}{ Basophils (\%) } & I & $0.48 \pm 0.07$ & $0.50 \pm 0.05$ \\
\hline & II & $0.40 \pm 0.07$ & $0.47 \pm 0.10$ \\
\hline & III & $0.28 \pm 0.11$ & $0.48 \pm 0.09$ \\
\hline \multirow{3}{*}{ Lymphocytes (\%) } & I & $64.20^{\mathrm{a}} \pm 0.12$ & $64.32^{\mathrm{a}} \pm 0.21$ \\
\hline & II & $38.35^{\mathrm{c}} \pm 0.18$ & $63.07^{\mathrm{b} * * *} \pm 0.23$ \\
\hline & III & $39.02^{\mathrm{b}} \pm 0.33$ & $64.33^{\mathrm{a}^{* * *}} \pm 0.12$ \\
\hline \multirow{3}{*}{ Monocytes (\%) } & I & $3.28^{\mathrm{a}} \pm 0.04$ & $3.32 \pm 0.04$ \\
\hline & II & $2.50^{\mathrm{b}} \pm 0.07$ & $3.27^{* *} \pm 0.03$ \\
\hline & III & $2.58^{\mathrm{b}} \pm 0.07$ & $3.35^{* *} \pm 0.03$ \\
\hline
\end{tabular}


Table. 2 Biochemical changes in healthy and diarrhoeic animals on day 0 and 5

\begin{tabular}{|c|c|c|c|}
\hline \multirow[t]{2}{*}{ Parameters } & \multirow[t]{2}{*}{ Groups } & \multicolumn{2}{|c|}{ Treatment intervals (Days) } \\
\hline & & 0 & 5 \\
\hline \multirow{3}{*}{$\begin{array}{l}\text { Blood glucose } \\
\quad(\mathbf{m g} / \mathbf{d l})\end{array}$} & I & $65.40^{\mathrm{a}} \pm 0.60$ & $65.59^{\mathrm{b}} \pm 0.55$ \\
\hline & II & $36.40 \pm 0.37$ & $61.74^{\mathrm{d}^{* *}} \pm 0.20$ \\
\hline & III & $36.44^{\mathrm{b}} \pm 0.62$ & $66.88^{\mathrm{a}^{* * *}} \pm 0.28$ \\
\hline \multirow{3}{*}{ Total protein(g/dl) } & I & $6.94^{\mathrm{b}} \pm 0.14$ & $6.94 \pm 0.14$ \\
\hline & II & $7.71^{\mathrm{a}} \pm 0.04$ & $6.86^{* *} \pm 0.04$ \\
\hline & III & $7.81^{\mathrm{a}} \pm 0.06$ & $7.04^{* *} \pm 0.03$ \\
\hline \multirow{3}{*}{ Albumin (g/dl) } & I & $3.60^{\mathrm{b}} \pm 0.07$ & $3.62 \pm 0.07$ \\
\hline & II & $4.79^{\mathrm{a}} \pm 0.05$ & $3.62^{* *} \pm 0.08$ \\
\hline & III & $4.87^{\mathrm{a}} \pm 0.05$ & $3.78^{* *} \pm 0.03$ \\
\hline \multirow{3}{*}{ Globulin (g/dl) } & I & $3.34^{\mathrm{a}} \pm 0.07$ & $3.32 \pm 0.08$ \\
\hline & II & $2.89^{\mathrm{b}} \pm 0.02$ & $3.23^{* *} \pm 0.06$ \\
\hline & III & $2.96^{\mathrm{b}} \pm 0.01$ & $3.26^{* *} \pm 0.03$ \\
\hline \multirow[t]{3}{*}{ A:G ratio } & I & $1.08^{\mathrm{b}} \pm 0.02$ & $1.09 \pm 0.02$ \\
\hline & II & $1.57^{\mathrm{a}} \pm 0.07$ & $1.13^{* *} \pm 0.05$ \\
\hline & III & $1.66^{\mathrm{a}} \pm 0.02$ & $1.16^{* *} \pm 0.02$ \\
\hline \multirow{3}{*}{ AST (U/L) } & I & $16.59 \pm 0.18$ & $16.90 \pm 0.23$ \\
\hline & II & $16.46 \pm 0.18$ & $16.59 \pm 0.09$ \\
\hline & III & $16.53 \pm 0.15$ & $16.79 \pm 0.18$ \\
\hline \multirow{3}{*}{$\operatorname{ALT}(\mathbf{U} / \mathbf{L})$} & I & $37.18 \pm 0.23$ & $37.23 \pm 0.18$ \\
\hline & II & $37.25 \pm 0.20$ & $37.19 \pm 0.22$ \\
\hline & III & $37.49 \pm 0.19$ & $37.61 \pm 0.13$ \\
\hline \multirow{3}{*}{$\begin{array}{l}\text { Serum sodium } \\
(\mathbf{m m o l} / \mathbf{l})\end{array}$} & I & $146.00^{\mathrm{a}} \pm 0.21$ & $146.06^{\mathrm{b}} \pm 0.22$ \\
\hline & II & $125.85^{\mathrm{c}} \pm 0.40$ & $142.13^{\mathrm{d}^{* *}} \pm 0.24$ \\
\hline & III & $127.63^{\mathrm{b}} \pm 0.35$ & $147.23^{\mathrm{a}^{* * *}} \pm 0.28$ \\
\hline \multirow{3}{*}{$\begin{array}{l}\text { Serum potassium } \\
(\mathrm{mmol} / \mathrm{l})\end{array}$} & I & $4.74^{c} \pm 0.13$ & $4.82^{\mathrm{a}} \pm 0.11$ \\
\hline & II & $6.32^{a b} \pm 0.17$ & $4.98^{\mathrm{a}^{* * *}} \pm 0.05$ \\
\hline & III & $6.78^{\mathrm{a}} \pm 0.34$ & $4.83^{\mathrm{a}^{* *}} \pm 0.11$ \\
\hline
\end{tabular}




\section{Rumen bacteria}

\section{Gram staining}

Gram's staining of the rumen fluid revealed that number of Gram positive bacteria were increased in the animals of group II and III as compared to predominantly Gram negative populated rumen fluid in the animals of group I(Healthy control) on day 0 . However, on day 5 following treatment the numbers of Gram negative bacteria population were predominant in rumen fluid in animals of group I and III as compared to group II.

The result of present study indicated that population of gram negative bacteria were reduced in rumen fluid of diarrhoeic cattle on the day of presentation (day 0). However, animals treated with antibiotic alone (group II) showed low population of gram negative bacteria in rumen fluid on day 5 following treatment.

Presumably, in the present therapeutic trial the increase in rumen microflora in animals treated with synbiotics might be due to a synergistic effect in the stimulation of gut microbiota (Shakira et al., 2018).

Methylene blue reduction test (MBRT, minutes)

A highly significant $(\mathrm{p}<0.01)$ decrease in MBRT values was recorded in the animals of group III on day 5 following treatment as compared to group II. The delayed clearing of the dye might me due to indicated diminished anaerobic bacteria activity (Fubini and Ducharme, 2004). Presumably, in the present therapeutic trial, the decrease in MBRT in animals treated with synbiotics might be due to a synergistic effect of symbiotic for stimulation of gut microflora (Shakira et al., 2018).

\section{Rumen protozoa}

\section{Microscopic examination of protozoa}

The protozoan motility in animals of group III increased as the treatment proceeded. A nonsignificant decrease in protozoan motility values in animals of group II was recorded in treated animals. The findings in the present study are in corroboration with the findings of by Petrovaski et al., (2017). The lower motility and reduction in number of protozoa were responsible for reduced grades of motility and protozoal activity observed and indicated that there was a disturbance in the ruminal environment.

The sluggish motility and low number of protozoa observed in the present study also might be attributed to factors like induced sub- acute rumen acidosis, fall in the $\mathrm{pH}$ of rumen contents and anorexia which could cause undesirable changes in microbial population (Arsat et al., 2015).

Presumably, in the present therapeutic trial, the vigorous protozoan motility and optimum concentration per field in animals treated with synbiotics might be due to the effect that certain yeast are particularly effective at raising and stabilizing ruminal $\mathrm{pH}$ by stimulating certain populations of ciliate protozoa, which rapidly engulf starch and, thus, effectively compete with amylolytic lactate producing bacteria (Shakira et al., 2018).

In conclusion, antibiotics alter the gut microflora composition and decrease its richness and diversity. However, synbiotics improve the ruminal and intestinal microbial balance. Hence, synbiotics are effective in raising and stabilizing ruminal $\mathrm{pH}$ by stimulating certain populations of ciliate protozoa. 


\section{References}

Asrat, M., Manohar, M. and Melkamu, S. (2015). Clinical and rumen fluid evaluation of ruminal disorders in cattle. Journal of Animal Research, 5(2): 359-372.

Asati, C.K., Roy, S. and Roy, M. (2008). Hematobiochemical study and diagnosis of colibacilosis in calves. Intas Polivet, 9(II): 245-248.

Bywater, R.J. (1977). Evaluation of an oral glucose-glycine- electrolyte formulation and amoxicillin for the treatment of diarrhoea in calves. American journal of veterinary research, 38, 1983-1987.

Fisher, E.W. and Dela Fuente, G.H. (1971). Water and electrolyte studies in new born calves with particular reference to the effect of diarrhoea. Research in Veterinary Science, 13, 315-322.

Fubini, S.L. and Ducharme, N.G. (2004). Surgery of ruminant fore-stomach compartment. In Farm Animal Surgery. S.L. Fubini and N.G. Ducharme (Eds), Saunders, Elsevier, pp. 161-240.

Galbat S. A., El-Shemy A. and Keshta. H. G. (2015). Clinical, hematological and some biochemical alterations in calves during diarrhea. International Journal of Advanced Research, 3(12): 191-196.

Habeeb, A. A. M. (2017). Importance of Yeast in Ruminants Feeding on Production and Reproduction. Ecology and Evolutionary Biology, 2(4), 49.

Hirschhom, N., and Greenough III, W.B. (1991). Progress in oral rehydration therapy. Scientific American. 264, 50-56.

Jain, V. K., Sindhu, N., Kumar, T., Jhambh, R., Kumar, M. and Goel, P. (2016). Clinical and Haematological Studies in Buffaloes Suffering from Diarrhoea. Journal of Animal Research, 6(6): 1025-1029.

Kaneko, J.J., Harvey, J.W. and Bruss, M.L. (2008). Clinical Biochemistry of Domestic Animals. Elsevier Academic Press, 6th ed., Amsterdam, London, p 891.

Lewis, L.P., Phillip, R.W. and Elliot, C.D. (1975). Changes in plasma glucose and lactate concentration and enzyme activities in the neonatal calf with diarrhoea. American journal of veterinary research, 36, 413-16.
Liu, J., Zhao, Z., Orfe, L., Subbiah, M. and Call, D. R. (2016). Soil- borne reservoirs of antibiotic- resistant bacteria are established following therapeutic treatment of dairy calves. Environmental microbiology, 18(2): 557-564.

Malik, S., Kumar, A., Verma, K. A., Gupta, K. M., Sharma, D. S., Sharma, K.A. and Rahal, A. (2013). Haematological profile and blood chemistry in diarrhoeic calves affected with Colibacillosis. Journal of Animal Health and Production, 1(1): 10-14.

Manickam, R. and Ponnusamy, P. (2017). Bacterial species isolated from diarrhoeic calves and its antibiotic sensitivity pattern. International Journal of Science, Environment and Technology, 6(4):2202 2211.

Morris, J.A., Weils, G.A.H., Scott, A.C. and Sojka, W.J. (1985). A comparison of methods for demonstrating colonization in the small intestine of piglets by enterotoxigenic E. coli. British Veterinary Journal, 141, 484-489.

Petrovski, K. R. (2017). Assessment of the Rumen Fluid of a Bovine Patient. Journal of Dairy \& Veterinary Sciences, 2(3): 2573-2196.

Radostits, O.M., Gay, C.C., Hinchcliff, K.W. and Constable, P.D. (2010). Disease of the alimentary tract. Veterinary Medicine: A Textbook of Disease of Cattle, Sheep, Pigs, Goats and Horses. 10th Edn. Saunders publication co., Oxford, London.

Ravi, K., Vamsi Krishna, B. and Boobalan, G. (2015), Adverse Effects of Routinely Used Drugs In Animal Husbandry Practice. Pharma Science Monitor, 6(4): 33-38.

Rekha, H. K. M., Puttalakshmamma, G. C., D'Souza, P. E., Ananda, K. J. and Rao, S. (2011). Hematological and biochemical changes due to cryptosporidiosis in bovines. Journal of Veterinary Parasitology, 25(2): 135-138.

Roy S., Roy, M., Asati, C. K. and Viswakarma, P. (2009). Colibacillosis in calves-Its prevalence and therapeutic management. IntasPolivet, 10, 207-211.

Schalm OW, Jain NC and Carrol EJ (1975). Veterinary Haematology 3rd edn. Lea and Febiger Publication, Philadelphia.

Sharma, P. K., Prajapati, K. A. and Choudhary, 
M. K. (2016). Effect of Probiotic Supplementation on Growth Performance of Pre-Ruminant Buffalo Calves. Journal of Krishi Vigyan, 4(2): 37-39.

Shakira, G., Qubtia, M., Ahmed, I., Hasan, F., Anjum, M. I. and Imran, M. (2018). Effect of indigenously isolated Saccharomyces cerevisiae probiotics on milk production, nutrient digestibility, blood chemistry and fecal microbiota in lactating dairy cows. JAPS, Journal of Animal and Plant Sciences, 28(2): 407-420.

Shekhar, S., Ranjan, R., Singh, C. V. and Kumar, P. (2017). Prevalence, Clinicohaematobiochemical Alterations in Colibacillosis in Neonatal Calves. International Journal of Current Microbiology and Applied Science, 6(9): 3192-3198.

Shrivastava, S., Misraulia, K. S., Gopal Reddy, A. Garg, U. K. Sharma, R. K. and Joshi, S. (2001). Studies on the efficacy of various therapeutic regimens with reference to biochemical alterations in colibacillosis in calves. Indian veterinary medical journal, 25, 95-96.

Singh, M., Gupta, V. K., Mondal, D. B., Bansal, S. K., Sharma, D. K., Shakya, M. and Gopinath, D. (2014). A study on alteration in Haemato-biochemical parameters in Colibacillosis affected calves. International Journal, 2(7): 746-750.

Smith BP. (1996). Large animal internal medicine. Disease of horses, cattle, sheep and goats. 2nd ed, Mosby, USA.

Szancer, J. (1980). Occurrence of 'O' antigens $E$. coli strain from calves with diarrhoea in the East Bohemiam region. VeterinariMedicina, 25, 329-38.

Snedecor, G. W. and Cochran, W. G. (1994). Statistical methods (8th edition): Oxford \& IBH Publishing Co. Calcutta, India.

Verstegen, M. W. and Williams, B. A. (2002). Alternatives to the use of antibiotics as growth promoters for monogastric animals. Animal biotechnology, 13(1): 113-127.

Walker, P. G., Constable, P. D., Morin, D. E., Foreman, J.H., Drackley, J. K. and Thurmon, J.C. (1998). Comparison of hypertonic saline-dextran solution and lactated Ringer's solution for resuscitating severely dehydrated calves with diarrhoea, Journal of the American Veterinary Medical Association, 213, 113-22.

Ward, D.E. (1976). Pathophysilogy of enteric colibacilllosis in the intact neonatal calf. Dissert. Abs. Int., 37 (B): 1133-34.

\section{How to cite this article:}

Rashmi Lata Rakesh, B. Roopali, M. Roy, S. Roy, S. K. Sidar, R. S. Kashyap, H. K. Ratre and Singh, J. 2020. Efficacy of Synbiotics as an Adjunct to Antibiotic Therapy in Diarrhoeic Cattle. Int.J.Curr.Microbiol.App.Sci. 9(01): 2095-2106. doi: https://doi.org/10.20546/ijcmas.2020.901.238 